\title{
Kecakapan Guru Pendidikan Agama Islam dalam Mengoptimalkan Pembelajaran Berbasis Teknologi
}

\author{
Abdul Mun'im Amaly*, Giantomi Muhammad, Muhammad Erihadiana, \& Qiqi \\ Yuliati Zaqiah
}

Sekolah Tinggi Agama Islam Darul Falah; Universitas Islam Negeri Sunan Gunung Djati. Jl. Raya Cihampelas No. 12 Desa Cihampelas Kec. Cihampelas KBB, Bandung, Indonesia; Jl. A.H. Nasution No. 105A, Cibiru, Bandung, Indonesia.

Email: abdulmunimamaly@gmail.com

\begin{abstract}
There are several Islamic Religious Education teachers who are still lacking in technology development is a concern in the education process. Therefore, efforts are needed to improve the skills of Islamic Religious Education teachers in optimizing technology-based learning. Using a case study approach and data collection techniques through in-depth interviews. Interviews were conducted with principals, vice principals in the field of curriculum, and Islamic religious education teachers, and were analyzed using data display, reduction, and interpretation techniques. This study found that educational technology is applied in the learning process which is integrated with various other technologies, both with hardware such as computers/laptops or smartphones, either with software such as homemade applications or open source applications. Optimization is done by; understand the content of learning materials; adjust the scope of learning strategies; and develop scientific knowledge. This research has implications for the development of the theory of "teacher competence in technology-based education" in learning.
\end{abstract}

Keywords: Teachers, Islamic Religious Education, Educational Technology, E-Learning

Abstrak: Banyaknya guru Pendidikan Agama Islam yang masih kurang dalam pengembangan teknologi menjadi kekhawatiran tersendiri dalam proses pendidikan. Oleh karenya dibutuhkan upaya peningkatan kecakapan guru Pendidikan Agama Islam dalam mengoptimalkan pembelajaran berbasis teknologi. Menggunakan pendekatan studi kasus dan teknik pengumpulan data melalui wawancara mendalam. Wawancara dilakukan kepada kepala sekolah, wakil kepala sekolah bidang kurikulum, dan guru pendidikan agama Islam, dan dianalisis dengan teknik display data, reduksi, dan interpretasi. Penelitian ini menemukan bahwa teknologi pendidikan diterapkan dalam proses pembelajaran yang diintegrasikan dengan berbagai teknologi lainnya baik dengan hardware seperti komputer/laptop atau smartphone, baik dengan software seperti aplikasi buatan sendiri ataupun aplikasi open source. Pengoptimalan dilakukan dengan; memahami konten materi pembelajaran; menyesuaikan ruang lingkup strategi pembelajaran; dan mengembangkan wawasan ilmu pengetahuan. Penelitian ini berimplikasi pada pengembangan teori "kompetensi guru dalam pembelajaran berbasis teknologi" dalam pembelajaran.

Kata Kunci: Guru, Pendidikan Agama Islam, Teknologi Pendidikan, E-Learning

Jurnal Pendidikan Agama Islam Al-Thariqah Vol. 6, No. 1, Januari - Juni 2021

Received : 17 April 2021; Accepted : 20 Juni 2021; Published : 30 Juni 2021

*Corresponding Author : abdulmunimamaly@gmail.com 


\section{PENDAHULUAN}

Perkembangan dunia sekarang ini tidak terlepas dari teknologi informasi dan komunikasi. Hal ini sebagaimana yang diungkap dalam penelitian bahwa tantangan kondisi saat ini di antaranya perkembangan IPTEK, yang semakin cepat dan banyak perubahan, dan laju teknologi komunikasi informasi yang tinggi (Yazdi, 2012; Ahmad, et al. 2018). Hal senada juga disampaikan Wijaya et al. (2016) bahwa abad 21 ditandai dengan berkembangnya teknologi informasi yang sangat pesat serta perkembangan otomasi di mana banyak pekerjaan yang sifatnya pekerjaan rutin dan berulang-ulang mulai digantikan oleh mesin, baik mesin produksi maupun komputer. Sebagaimana sudah diketahui dalam abad ke 21 ini sudah berubah total baik masyarakat maupun dunia pendidikannya. Pada abad ini juga pendidikan lebih memanfaatkan teknologi digital (cyber system) dalam proses pembelajaran. Dengan penggunaan teknologi tersebut memungkinkan proses pembelajaran berlangsung tidak terbatas ruang dan waktu, dengan arti proses pembelajaran tidak hanya diruang kelas dan pada saat jam belajar (Surani, 2019).

Melihat dinamika zaman yang begitu pesat maka perkembangan pada abad 21 ini perlu direspon oleh dunia pendidikan terutama guru yang menjadi salah satu komponen utama dalam pendidikan yakni dalam kegiatan belajar mengajar peserta didik (Sawaluddin, 2018). Hal ini dianggap perlu untuk merespons dan menerapkan teknologi dalam pendidikan khususnya juga dalam pembelajaran apalagi pendidikan agama Islam, karena jika tidak mengubah cara mendidik dan belajar mengajar, maka 30 tahun mendatang kita akan mengalami kesulitan besar (Melani, 2018).

Guru perlu mengembangkan kompetensi yang dimilikinya bukan hanya sebatas pada kemampuan mengajarkan yang menggunakan metode klasik saja, tetapi juga mampu menciptakan media, model, dan metode pengajaran yang kekinian seperti sekarang ini, di mana teknologi menjadi sebuah keharusan dan kebutuhan pokok. Apalagi pada masa pandemi Covid-19 sekarang ini yang masih belum pasti kesudahannya. Penguasaan teknologi yang dimiliki seorang guru akan mempermudah proses pembelajaran yang selama ini dianggap monoton.

Sebagaimana yang sudah disampaikan bahwa pendidikan memiliki komponen-komponen yang saling berkaitan dan berhubungan, di mana bila salah satunya berkembang atau berubah maka komponen yang lainnya juga harus menyesuaikan dengan perkembangan dan perubahan yang terjadi. Komponen yang sangat penting dari komponen lainnya dalam pendidikan adalah guru, apalagi guru PAI (Syarif, 2017; Ahmad, and Tambak, 2018). Dikatakan demikian sebab ini berpengaruh besar dalam usaha mencapai pendidikan. Guru dalam Islam adalah orang-orang yang bertanggung jawab terhadap perkembangan peserta didik dengan mengupayakan perkembangan seluruh potensi peserta didik, baik potensi afektif, kognitif, maupun psikomotorik sesuai dengan nilai-nilai ajaran Islam. Karena pada dasarnya, nanti akan dimintai pertanggungjawaban atas pekerjaannya tersebut. Sebagaimana Firman Allah SWT Q.S. An-Nisa' Ayat 58 (Sunarti, 2017; Ahmad, Tambak, and Syafitri, 2016).

Oleh karenanya maka Sudarsana et al. (2018) dalam bukunya menyampaikan bahwa dengan sinerginya semua aspek/komponen pendidikan maka teknologi pendidikan akan mampu memerankan dirinya sebagai katalis dalam upaya meningkatkan kualitas pendidikan nasional. Kemampuan guru dalam menguasai teknologi dalam pembelajaran menurut Sintawati dan Indriani (2019) dapat dilihat melalui TPaCK (Technological Pedagogical Content Knowledge) yang dimiliki guru. 
Sejauh ini terdapat beberapa penelitian yang meneliti tentang pembelajaran berbasis teknologi. Penelitian yang dilakukan Sintawati dan Indriani (2019) mengungkap kerangka pemikiran dalam ranah pengajaran yang dilakukan seorang guru, dalam hal ini guru Pendidikan Agama Islam (PAI), dengan memaksimalkan teknologi dalam kegiatan pembelajarannya. Pada saat ini guru PAI memiliki tuntutan lebih, baik dalam kompetensi maupun kemampuan untuk melakukan inovasi pembelajaran. Jika guru PAI abai dalam penguasaan teknologi, tidak kreatif, dan inovatif, maka guru akan bisa digantikan teknologi. Maka guru PAI selain melek literasi digital juga menempatkan diri sebagai motivator dan inspirator (Maghfiroh and Nurhayati, 2020).

Walau telah terdapat berbagai penelitian yang meneliti tentang pembelajaran berbasisi teknologi, namun hal itu masih tetap menjadi permasalahan dalam dunia pendidikan Islam. Berbagai guru masih saja tampak kesulitan dalam mengembangkan pembelajaran berbasisi teknologi, terutama dalam pendidikan agama Islam. Sehubungan dengan ini, SMA Darul Falah Cihampelas sebagai lembaga pendidikan juga memiliki informasi teknologi, dalam rangka menyikapi dan menjawab segala perubahan dan perkembangan yang terjadi di era globalisasi, yaitu khususnya dalam bidang pendidikan. Serta perannya dalam meningkatkan mutu pendidikan khususnya pendidikan Agama Islam, yang mana dengan memanfaatkan perkembangan informasi teknologi. Di samping itu SMA Darul Falah Cihampelas juga memanfaatkan informasi teknologi lainnya, yang mana hal tersebut dapat menunjang dan meningkatkan mutu pembelajaran pendidikan Agama Islam, di antaranya: perangkat lunak seperti penggunaan aplikasi sekolah berbasis android, web, aplikasi komputasi, internet, email, dan perangkat keras seperti komputer/laptop, proyektor dan lainnya.

Maka untuk mengatasi hal tersebut dibutuhkan pengembangan pembelajaran berbasis teknologi dalam pendidikan agama Islam oleh guru-guru pendidikan agama Islam di sekolah. Oleh karenanya maka Sudarsana et al. (2018) dalam bukunya menyampaikan bahwa dengan sinerginya semua aspek/komponen pendidikan maka teknologi pendidikan akan mampu memerankan dirinya sebagai katalis dalam upaya meningkatkan kualitas pendidikan nasional. Kemampuan guru dalam menguasai teknologi dalam pembelajaran menurut Sintawati dan Indriani (2019) dapat dilihat melalui TPaCK (Technological Pedagogical Content Knowledge) yang dimiliki guru.

Penelitian ini sangat urgen dalam mengembangkangkan pembelajaran berbasis teknologi dalam pendidikan agama Islam oleh guru-guru pendidikan agama Islam di sekolah. Sebab melihat dinamika zaman yang begitu pesat maka perkembangan pada abad 21 ini perlu direspon oleh dunia pendidikan terutama guru yang menjadi salah satu komponen utama dalam pendidikan yakni dalam kegiatan belajar mengajar peserta didik (Sawaluddin, 2018; Tambak, and Sukenti, 2020). Hal ini dianggap perlu untuk merespons dan menerapkan teknologi dalam pendidikan khususnya juga dalam pembelajaran apalagi pendidikan agama Islam, karena jika tidak mengubah cara mendidik dan belajar mengajar, maka 30 tahun mendatang kita akan mengalami kesulitan besar (Melani, 2018).

Maka fokus penelitian ini adalah; kecakapan guru pendidikan agama Islam dalam mengembangkan pembelajaran berbasis teknologi; dan optimalisasi peran pendidikan agama Islam dalam mengembangkan pembelajaran pendidikan agama Islam berbasis teknologi pendidikan. Dengan demikian ditemukan kecakapan guru pendidikan agama Islam dalam mengoptimalisasi 
pembelajaran berbasis teknologi pendidikan di sekolah.

\section{KONSEP TEORI}

Sebagaimana yang sudah dipaparkan sebelumnya, guru dituntut menguasai teknologi untuk diintegrasikan dalam proses pembelajaran. Hal ini sesuai dengan peraturan menteri pendidikan nasional no. 16 tahun 2007 yang menyatakan bahwa seorang guru harus mempunyai kompetensi di bidang teknologi informasi dan komunikasi. Kompetensi di bidang teknologi informasi dan komunikasi berfungsi untuk mengembangkan diri dan sebagai penunjang proses pembelajaran. Pernyataan tersebut dikuatkan dengan Permendikbud no. 22 tahun 2016 dalam standar proses yaitu prinsip pembelajaran yang digunakan adalah guru harus dapat memanfaatkan teknologi informasi dan komunikasi untuk meningkatkan efisiensi dan efektivitas pembelajaran (Sintawati and Indriani, 2019). Terutama guru pendidikan agama Islam, yang mempunyai peranan sangat penting dalam pendidik peserta didik untuk dapat siap survive bukan hanya di dunia sebagai tempat tinggal sekarang ini namun juga di akhirat sebagai tempat tinggal nanti.

Oleh karenanya maka guru pendidikan agama Islam dalam kompetensinya perlu mengembangkan dan bahkan menciptakan konsep baru pembelajaran yang terintegrasi optimal dengan teknologi, sehingga teknologi tersebut dapat bermanfaat dalam dunia pendidikan. Pratama and Haryanto (2017, 168) menyebutkan teknologi pendidikan berperan utama sebagai disiplin ilmu yang memfasilitasi pembelajaran agar terjadi secara efektif dan efisien. Berkaitan dengan hal ini, Nasution (2018) mengungkapkan manfaat teknologi dalam proses pembelajaran yaitu, 1) bagi siswa meningkatkan perhatian, konsentrasi, motivasi, dan kemandirian, 2) bagi guru dapat mereduksi penggunaan waktu penyampaian materi, membuat pengalaman belajar siswa lebih menyenangkan, mendesain materi lebih menarik, dan mendorong guru untuk meningkatkan pengetahuan dan kemampuan mengenai komputer atau teknologi lainnya. Penguasaan teknologi yang optimal dipadukan dengan penguasaan pengajaran dari seorang guru akan menciptakan harmonisasi dan dinamika pembelajaran yang kreatif. Maka peran teknologi informasi dan komunikasi adalah sebagai instrumen teknologi pembelajaran interaktif.

Banyak ragam teknologi yang dapat diterapkan untuk model pembelajaran yang kompetitif Salah satunya adalah $e$ learning (Yazdi, 2012). Di mana e-learning merupakan kegiatan pembelajaran yang memanfaatkan jaringan (internet, LAN, dan WAN) sebagai metode penyampaian, interaksi, dan fasilitasi serta didukung oleh berbagai bentuk layanan belajar lainnya (Hadisi and Muna, 2015). Rosyad (2019) menguatkan dalam penelitiannya bahwa e-learning merupakan suatu jenis media pembelajaran yang diterapkan dalam dunia pendidikan dengan memanfaatkan teknologi informasi dan komunikasi. Hampir beberapa sekolah sudah menerapkan e-learning untuk jenjang pendidikan dasar, menengah, dan pendidikan tinggi. Penggunaan elearning/pembelajaran online tidak harus membutuhkan biaya yang mahal dan prosedur yang sulit. Namun penggunaannya kita bisa memakai google classes, edmodo, info guru, dan lain sebagainya.

Dengan e-learning, pembelajaran dapat digunakan di manapun dan kapanpun (Pratama and Haryanto, 2017). Lase (2019) juga menyampaikan dalam penelitiannya bahwa E-learning memfasilitasi kesempatan untuk pembelajaran jarak jauh dan mandiri. Sehingga seperti kondisi sekarang ini pembelajaran ajak tetap berjalan. Hal ini mengindikasikan bahwa pembelajaran berbasis teknologi atau e-learning tidak lagi sekedar wacana atau sebatas visi, 
melainkan sudah harus menjadi aksi nyata pada semua jenjang pendidikan mulai dari pendidikan dasar hingga perguruan tinggi. Hal yang menjadi persoalan ialah rendahnya kuantitas lembaga pendidikan yang menyelenggarakan proses pembelajaran berbasis teknologi informasi dan komputer (Lase, 2019).

\section{METODE PENELITIAN}

Metode yang digunakan dalam penelitian ini adalah metode kualitatif dengan pendekatan studi kasus. Dalam penelitian ini peneliti menggunakan penelitian lapangan (field research), lokasi yang dijadikan objek penelitian adalah Sekolah Menengah Atas (SMA) Darul Falah, Cihampelas, Kabupaten Bandung Barat, Provinsi Jawa Barat, Indonesia dengan keunggulan teknologi dalam pendidikan.

Informan penelitian ini adalah, guru pendidikan agama Islam, kepala sekolah, dan wakil kepala sekolah bidang kurikulum. Pengumpulan data penelitian, peneliti menggunakan teknik wawancara. Selanjutnya dilakukan triangulasi data dengan mencari berbagai sumber data, yang dilakukan dengan wawancara kepada narasumber terkait dari pihak SMA Darul Falah terdiri dari Kepala Sekolah, Bagian Kurikulum, dan guru terkait untuk menemukan data mengenai kecakapan Guru Pendidikan Agama Islam (PAI) dalam mengoptimalkan pembelajaran berbasis teknologi pendidikan.

Dilakukan juga teknik analisis data, pengumpulan data yang dilakukan dengan wawancara kepada Kepala Sekolah, Bagian Kurikulum, dan Guru Pendidikan Agama Islam sebagai proses awal yang harus ditemukan, selanjutnya dilakukan reduksi data untuk menyederhanakan data wawancara terkait agar dipusatkan pada pokok pembahasan yang diteliti, tahapan berikutnya dilakukan penyajian data dengan menyandingkan hasil kesimpulan wawancara dengan pihak SMA Darul Falah untuk proses analisis agar mudah memahami tujuan dari hasil pengolahan data. Langkah terakhir yaitu dilakukan proses kesimpulan dari proses analisis data yang telah peneliti lakukan.

\section{HASIL DAN PEMBAHASAN Teknologi Pendidikan}

Teknologi pada saat ini tidak terlepas dari ruang lingkup kehidupan keseharian. Teknologi menjadi alat untuk mempermudah segala aktivitas sehingga dahulu yang sulit dijangkau sekarang dengan keberadaan teknologi semakin mudahnya menjangkau yang dahulu susah. Sistem pendidikan yang ada saat ini tidak luput dalam mengkombinasikan teknologi dengan penerapan pendidikan yang ada. Oleh karenanya tidak asing di kalangan akademisi dan praktisi pendidikan saat ini istilah dari dari teknologi pendidikan.

Teknologi pendidikan merupakan sistem yang digunakan dalam rangka mendukung proses pembelajaran hingga tujuan yang diharapkan tercapai (Lestari, 2018). Teknologi pendidikan memberikan kemudahan dalam mencapai tujuan dari pembelajaran yang diterapkan. Teknologi pendidikan sebagai suatu yang kompleks dan terintegrasi sesuai dengan apa yang disampaikan oleh Ariani (2017) bahwasannya teknologi pendidikan merupakan proses yang terintegrasi dan kompleks, keterkaitan tersebut meliputi orang, masyarakat, organisasi atau lembaga dengan mendesain proses pembelajaran berbasis teknologi sebagai upaya dalam mencapai hasil dan tujuan dari pendidikan dan pembelajaran.

Perkembangan zaman yang kian mengglobal menjadikan teknologi pendidikan di Korea Selatan sebagai suatu kompetensi yang harus masuk dalam kurikulum seni praktik (pratical arts curriculum), setiap siswa dan guru di Korea Selatan dituntut untuk mengembangkan ilmu pengetahuan berbasis teknologi dengan kompetensi kurikulum tersebut dan sudah diimplementasikan pada tingkat Sekolah 
Dasar dan tuntutan guru untuk dapat menyempurnakan pelaksanaan kurikulum seni praktik (Go, 2021; Ahmad, and Tambak, 2018).

Pada pengkajiannya teknologi pendidikan dipahami sebagai pendekatan yang menjadi alternatif problem solving method atau yang kita kenal dengan metode pemecahan masalah dalam kegiatan belajar mengajar (Nurdin, 2016). Selain itu teknologi pendidikan jika dilihat dari segi praktik pedagogisnya dimaknai sebagai proses kegiatan belajar mengajar yang menggunakan teknologi (Subkhan, 2016). Dengan demikian teknologi pendidikan merupakan sarana pembelajaran dalam mengintregrasikan teknologi dengan sasaran pembelajaran yang komplek, untuk mempermudah proses pengajaran dan pembelajaran sehingga upaya dalam pencapaian hasil dan tujuan pendidikan dapat terlaksana dengan baik juga mengoptimalisasikan proses-proses pendidikan dan pengajaran kepada peserta didik.

Berkenaan dengan penciptaan teknologi ini, yang didasarkan atas upaya pemecahan masalah, maka dalam kondisi pandemi Covid-19 SMA Darul Falah melakukan sebuah inovasi, dengan menciptakan sebuah website yang menjadi homebased setiap kegiatan belajar mengajar. Selain itu SMA Darul Falah juga membuat aplikasi mobile berbasis android yang lebih fleksibel penggunaannya, dengan penggunaan teknologi tersebut permasalahan yang ada dalam kegiatan belajar mengajar dapat diatasi, bahkan efektif untuk meramalkan permasalahan tersebut.

Penciptaan inovasi teknologi pendidikan tersebut tentunya tidak dilakukan secara mandiri oleh pihak lembaga, tetapi SMA Darul Falah bekerja sama dengan pihak ketiga sebagai pengembang website dan aplikasi berbasis android (develover). Teknologi pendidikan memiliki perkembangan tersendiri dari masa kemasa sebagai upaya dalam memajukan proses pembelajaran.
Subkhan (2016) dalam bukunya mengungkapkan bahwasanya teknologi pendidikan yang ada sekarang ini memiliki perkembangan pada setiap masanya, yang dimana tujuan dari proses pengembangannya adalah untuk memudahkan guru dan kalangan akademisi dalam penyampaian proses pembelajaran sehingga dapat dipahami oleh peserta didik. Awalnya teknologi tersebut bukan ditujukan untuk pendidikan melainkan untuk memenuhi kebutuhan militer, dikatakan pula teknologi pendidikan mulanya berasal dari pengembangan produk elektronik

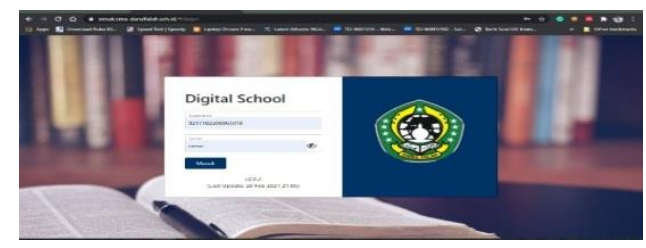

Gambar 2 Website E-Learning SMA Darul Falah
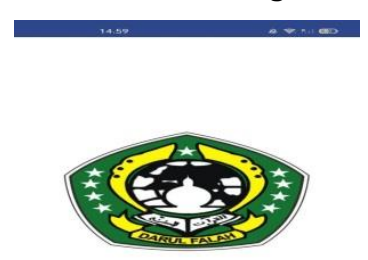

Gambar 2 Aplikasi SMA Darul

sebagai sarana hiburan dan komunikasi. Pada waktu itu teknologi pendidikan dikembangkan dengan dua pokok kajian yaitu media pembelajaran dan desain pengajaran (Subkhan, 2016; Nurdin, 2016)..

Penggunaan teknologi pendidikan merupakan usaha untuk menyediakan media pembelajaran, oleh karenanya media pembelajaran berbasis teknologi perlu dilakukan dengan baik dan dapat memikat peserta didik untuk dapat menyukainya. Media pembelajaran sendiri merupakan wadah untuk menyampaikan pesan dan informasi dalam kegiatan belajar mengajar. Hal ini perlu disusun secara baik karena akan sangat berguna pagi peserta didik guna menangkap dan 
memahami materi pelajaran. Adapun kegunaan media pembelajaran tidak hanya sebagai alat peraga bagi pendidik, tetapi juga sebagai sarana untuk menyampaikan pesan dalam kegiatan belajar mengajar. Setiap media pembelajaran mempunyai karakteristik, kelebihan dan kekurangannya. Oleh karena itu perlu melakukan perencanaan sistematis guna mengaplikasikan media dalam pembelajaran (Muhson, 2010; Tambak, Amril, and Sukenti, 2021). Menurut Suwastika (2018) media pembelajaran yang dipakai pada lembaga pendidikan baik formal atau nonformal bisa menambah motivasi belajar peserta didik. Maka dari itu sekolah pada abad-21 ini perlu mengaplikasikan media pembelajaran bersifat teknologi dalam rangka memotivasi peserta didik untuk belajar. Kecanggihan teknologi yang ada saat ini tidak boleh diabaikan melainkan perlu diiringi dengan ketersediaan yang dibutuhkan.

\section{Kecakapan Guru PAI dalam Pembelajaran Bebasis Teknologi}

Agar kegiatan belajar mengajar pendidikan agama Islam (PAI) dapat berlangsung dengan baik di tengah kondisi pandemi sekarang ini yang dibatasi dengan tidak diizinkannya pembelajaran tatap muka (PTM), dan diberlakukannya pembelajaran jarak jauh (PJJ) yakni belajar dari rumah, maka guru PAI marus membuat strategi dengan penguasaan teknologi. "Kami secara otomatis mesti melakukan pembalajaran jarak jauh dengan belajar menggunakan teknologi, media pembelajaran online, dan menggunakan aplikasi zoom," tegas salah seorang guru pendidikan agama Islam.

Hal ini sesuai dengn hasil penelitian Zulfikar (2018) bahwa dengan berkembangnya teknologi informasi khususnya pada sektor pendidikan, maka sekarang ini sangat mungkin melaksanakan proses belajar jarak jauh, seperti dengan media internet di mana guru dan siswa bisa saling berhubungan dalam kegiatan pembelajaran atau yang disebut dengan e-learning. Kecakapan guru terutama guru PAI dalam kemampuan teknologi pendidikan diperlukan motif dan kesejahteraan guru dalam mengembangkan wawasan keilmuan yang leluasa (Richter et al., 2021). Wakil kepala sekolah bidang kurikulum mengungkapkan bahwa "wadah yang menampung asosiasi guru PAI dalam mengembangkan kecakapan teknologi pendidikan perlu dilakukan, terutama dalam pelaksanaan pelatihanpelatihan tertentu yang menunjang pengembangan kemampuan guru PAI dalam menghadapi perkembangan zaman." Hal ini sejalan dengan hasil penelitian Lubis (2017) bahwa asosiasi yang menaungi guru sangat penting dalam mengembangkan kompetensi guru terutama dalam mengembangkan pembelajaran berbasis teknologi atau $e$ learning. Penyelenggaraan e-learning adalah stimulus dan komplemen terhadap pembelajaran biasa dilakukan di kelas sebagai upaya menumbuhkan pembelajaran yang berkualitas (Ramdani et al. 2018).

Pembelajaran berbasis e-learning yang digunakan oleh guru pendidikan agama Islam di SMA Darul Falah Cihampelas, Bandung adalah:

\section{Penggunaan Software Mobile App}

Agar pembelajaran dapat menyesuaikan dengan tuntutan global, maka proses belajar harus mengaplikasikan konsep electronic learning atau yang kemudian dikenal dengan e-learning, yang merupakan pembelajaran yang menjadikan teknologi sebagai sarana utamanya (Rosyad, 2019).

"SMA Darul Falah, khususnya guru PAI dalam kegiatan pembelajarannya, yakni dengan menggunakan aplikasi yang bernama SMA Darul Falah yang sudah tersedia di google play store." (3). Pada aplikasi tersebut "guru dan siswa bisa melakukan kegiatan yang senantiasa dilakukan ketika pembelajaran tatap 
muka (PTM), seperti melihat jadwal pelajaran, mengabsen, memberikan materi pembelajaran baik berupa teks, audio, visual, dan audio visual, baik berupa file ataupun link. Selain itu dengan aplikasi SMA Darul Falah tersebut juga dapat berdiskusi, memberikan tugas, memberikan nilai, sampai melakukan ujian via aplikasi tersebut" (1).

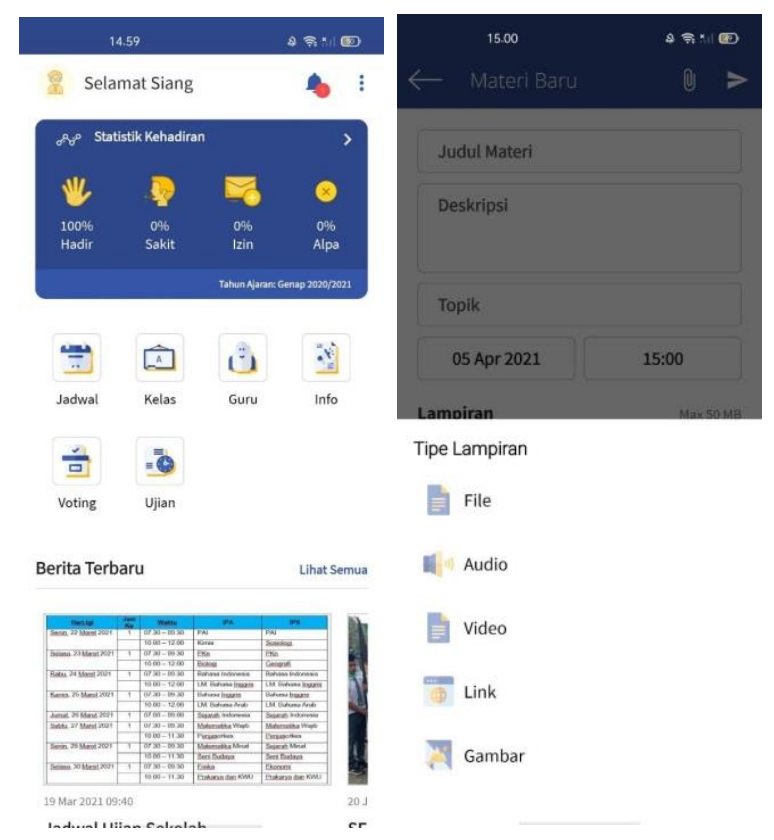

Gambar 3 Tampilan Menu Aplikasi SMA Darul Falah

Apa yang terjadi di SMA Darul Falah ini disambut dan diaplikasikan dengan baik oleh guru PAI, di mana "guru PAI dapat memberikan materi, tugas, kuis, dan nilai sebagai bentuk evaluasinya dengan penggunaan teknologi pendidikan yang kemudian diaplikasikan dalam pembelajaran terutama dalam kondisi Pembelajaran Jarak Jauh (PJJ) merupakan sebuah usaha untuk menjadikan kegiatan belajar lebih efektif juga lebih efisien" (2). Kepala sekolah SMA Darul Falah mengungkapkan bahwa "kondisi ini menuntut guru terutama guru PAI untuk tetap melaksanakan pembelajaran. Dengan adanya teknologi pendidikan ini membantu tetap terlaksananya kegiatan belajar mengajar".

Hasil penelitian ini sesuai dengan temuan penelitian Arif (2011) bahwa penggunaan teknologi informasi dan komunikasi dalam pembelajaran berdampak besar pada perubahan pola pikir dan kebiasaan guru dalam mengajar. Pembelajaran dapat bermakna dan memiliki nilai aksential pada peserta didik. Dengan adanya teknologi dalam pembelajaran, guru dapat mudah mengajar dalam mempersiapkan media pembelajaran berkualitas dan siswa pun lebih memiliki motivasi dan semangat dalam belajar.

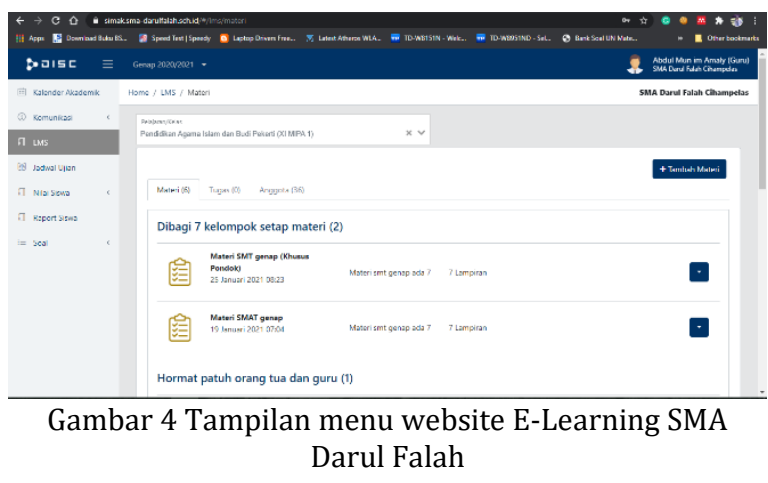

\section{Penggunaan Website}

Menurut kepala sekolah, "penggunaan website (lih. gambar 4) dalam ini digunakan oleh guru PAI di SMA Darul Falah dalam rangka pelaksanaan pembelajaran serta evaluasi pembelajaran, dimulai dengan pemberian materi, pembuatan soal, kunci jawaban, skor yang diberikan dan penilaian akhir yang diberikan." Di sisi lain dalam pandangan seorang guru, "penggunaan pembelajaran berbasis website berarti menjadikan internet sebagai sarana utama dalam pembelajaran, di mana semua unsur yang ada dalam kegiatan belajar mengajar sepenuhnya disampaikan melalui internet bahkan materi, tugas, ujian, dan diskusi" (2).

Hal tersebut sangat memudahkan guru PAI dalam memantau perkembangan peserta didik dan mengamankan data perkembangan peserta didik. Guru PAI harus mampu menguasai setiap menu yang ada pada website tersebut karena pada masa pandemi ini sudah pasti penilaiannya pun harus dilakukan secara online atau daring. (Ramdani et al., 2018; Nurdin, 2016; Ahmad, 2017). Selain kemudahan tersebut, kemudahan lain 
yang didapat di penggunaan website adalah karena dapat diakses anywhare dan everywhere selama tersambung dengan internet (Asiah, 2016).

\section{Aplikasi open source}

Selain penggunaan aplikasi di handphone dan website, "guru PAI di SMA Darul Falah juga menggunakan aplikasi lain dalam kegiatan pembelajarannya yang membutuhkan koneksi internet, seperti menggunakan google class room, zoom meeting, google meet, dan youtube" (1). Penggunaan aplikasi yang membutuhkan koneksi internet tersebut merupakan sarana komunikasi, multimedia dan media utama dalam penyampaian materi dan interaksi (Asiah, 2016; Nu'man, 2014).

Selain aplikasi yang menggunakan koneksi internet "guru PAI di SMA Darul Falah juga menggunakan aplikasi lain

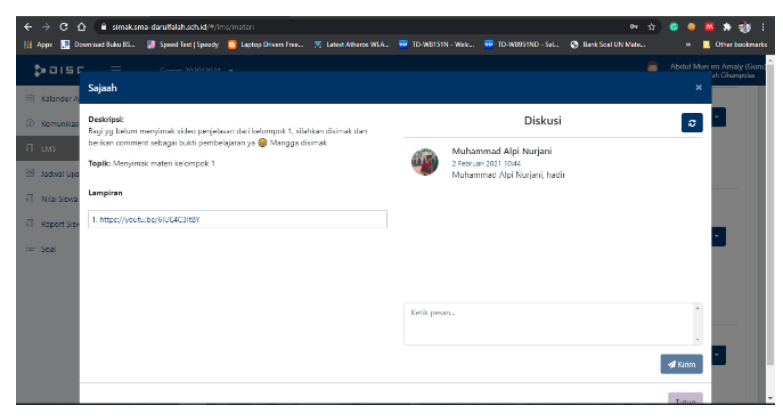

Gambar 5 Intergrasi berbagai aplikasi dengan web atau aplikasi SMA Darul Falah

yang tidak membutuhkan koneksi internet, seperti power point untuk menjelaskan dan mempresentasikan materi pelajaran, dan aplikasi pembuat video seperti kinemaster (2). Kepala sekolah mengungkapkan bahwa "penggunaan aplikasi yang tidak membutuhkan koneksi internet tersebut dikombinasikan dengan aplikasi yang terhubung menggunakan internet, seperti penggunaan power point dikombinasikan dengan google class room, zoom, dan google meet (lih. gambar 5). Penggunaan kinemaster dikombinasikan dengan google class room, zoom, google meet, dan youtube. Bahkan penggunaan aplikasi open source ini juga dikombinasikan dengan aplikasi SMA Darul Falah dan website Simak SMA Darul Falah."

Pengembangan kombinasi berbagai platform teknologi dalam pembelajaran dari berbagai aplikasi tersebut menurut Nurdin (2016) bisa memicu peserta didik menjadi lebih active learners dalam pembelajaran. Hal ini karena variasi yang dilakukan dalam pembelajaran dan berbagai keterampilan secara efisien dapat dicapai dengan baik. Pembelajaran lebih bermakna dan berdaya saing sehingga peserta didik berpartisipasi aktif dalam berbagai tugas yang diberikan oleh guru.

Institusi pendidikan (sekolah, perguruan tinggi, dan universitas) harus menyesuaikan dan mengaplikasikan teknologi pada metode pembelajaran. Merubah pola pembelajaran tradisional, dimana mereka mengikuti pengaturan tradisional tatap muka kuliah di sebuah kelas dengan penggunaan teknologi dalam proses pembelajaran. Pembelajaran berbasis teknologi dapat membantu guru dalam mengajar dan mempercepat siswa dalam belajar (Dhawan, 2020; Wei, 2020).

\section{Penggunaan Hardware}

Kecakapan guru dalam penggunaan teknologi dalam pembelajaran PAI, "dalam penggunaan software yang diterapkan dalam kegiatan belajar mengajar oleh guru PAI, tentunya tidak mungkin dilakukan tanpa adanya perangkat hardware. Oleh karenanya ketika guru PAI mampu menggunakan software harus mampu juga untuk menggunakan hardware dalam pelaksanaan pembelajarannya. Salah satunya yang paling banyak digunakan yakni komputer/laptop dan smartphone." (1). "Guru PAI di SMA Darul Falah, dituntut untuk dapat memaksimalkan pembelajaran berbasis komputer/laptop, apalagi di masa pandemi covid 19 ini." (2).

$$
\text { Penelitian Asiah }
$$
menguatrkan temuan penelitian ini bahwa guru dituntut untuk menguasai komputer. Karena penggunaan perangkat keras 
seperti komputer atau laptop dalam pembelajaran sangat berguna untuk memperluas paradigma keilmuan guru PAI itu sendiri. Pembelajaran berbasis teknologi guru menguasai berbagai perangkat teknologi dalam mengajar dan mempercepat siswa dalam belajar (Dhawan, 2020; Wei, 2020).

Wakil kepala sekolah bidang kurikulum mengungkapkan bahwa "penggunaan komputer/laptop dalam pembelajaran PAI sebagai wadah penampungan utama dari software yang sudah dijelaskan sebelumnya, di mana guru PAI di SMA Darul Falah mampu melakukan pembelajaran dengan aplikasi open source dan evaluasi berbasis website. Oleh karenanya dipastikan guru PAI di SMA Darul Falah mampu juga untuk menggunakan perangkat keras seperti komputer/laptop dalam proses pembelajaran maupun proses evaluasi." Menurut seorang guru, "kemampuan penggunaan komputer/ laptop guru PAI SMA Darul Falah tersebut akan memudahkan pelaksanaan sistem pembelajaran e-learning seperti pada situasi saat ini."

Temuan penelitian ini diperkuat oleh Yoon, Lee, and Jo (2021) bahwa pada pembelajaran daring saat ini, kemampuan guru dalam menggunakan teknologi infomasi dan komunikasi dalam pembelajaran menjadi keharusan. Sebab penggunaan teknologi dapat mempermudah guru dan peserta didik dalam pembelajaran untuk menyerap materi pembelajaran. Pembelajaran di masa pandemi Covid 19 mau tidak mau harus menggunakan teknologi dan guru dituntut untuk mampu melaksanakannnya secara maksimal. Pembelajaran tidak akan bermakna jika guru tidak memiliki kompetensi penggunaan teknologi pendidikan.

\section{Smartphone}

Menurut kepala sekolah, "penggunaan smartphone oleh guru PAI di SMA Darul Falah juga tidak dapat dipungkiri. Hal ini menilik dari apa yang telah disampaikan, bahwa dalam proses pembelajarannya guru PAI menggunakan mobile app berbasis android yang diberi nama SMA Darul Falah. Hal ini dimaksudkan karena penggunaan komputer/laptop yang tentunya kurang praktis apabila dibandingkan dengan smartphone yang bersifat portable."

Wakil bidang kurikulum mengungkapkan, "penggunaan smartphone dalam proses pembelajaran justru akan meningkatkan kinerja guru PAI dan siswa itu sendiri, karena dapat dilakukan di manapun, kapanpun dan tentunya praktis. Sehingga proses pembelajaran guru PAI di SMA Darul Falah lebih banyak ditekankan dan dioptimalisasikan penggunaannya dengan smartphone yang menghimpun mobile app yang juga sebagai sarana teknologi utama dalam kegiatan pembelajarannya."

Penggunaan smartphone dapat mengembangkan dan mempermudah pembelajaran. Smartphone menyebabkan tantangan pengendalian diri dalam kehidupan sehari-hari masyarakat. Sejalan dengan prediksi kami, siswa yang lebih tinggi dalam pengendalian diri sifat menunjukkan kinerja akademik yang lebih baik $(\beta=0,22)$. Penundaan smartphone $(\beta$ $=0,23)$ dan kebiasaan penempatan $(\beta=$ 0,21 ) secara signifikan terkait dengan kinerja akademik dan keduanya juga memediasi hubungan pengendalian dirikinerja. Jumlah penggunaan ponsel cerdas yang objektif tetapi penanganan ponsel cerdas yang efektif yang membantu siswa dengan pengendalian diri sifat yang lebih tinggi untuk berprestasi lebih baik secara akademis. Implikasi untuk penelitian masa depan dibahas dari perspektif pengaturan diri pada penggunaan smartphone (Troll, Friese, and Loschelder, 2021; Ignatov, et al. 2021). 
Optimalisasi Peran Guru PAI dalam Pembelajaran Berbasis Teknologi

Kecakapan guru PAI dalam menguasi dan mengendalikan teknologi pendidikan perlu diotimalkan dengan pembelajaran yang sedang diajarkannya, sehingga penyampaian materi yang dilakukan dapat dipahami oleh peserta didik dengan langkah-langkah yang dapat dimengerti. Teknologi pendidikan sebagai media pembelajaran menurut Ramdani dkk (2018) diperlukan langkah pengoptimalisasiannya, bukan sebatas menguasai tetapi tidak memahami langkah penerapannya sesuai materi yang sedang diajarkan oleh guru, akan tetapi menerapkannya dengan baik. Terdapat beberapa kecakapan guru PAI dalam pembelajaran berbasis teknologi pendidikan perlu dioptimalkan dengan tahapan-tahapan yang sesuai, yaitu:

\section{Memahami Konten Materi Pembelajaran}

Guru PAI sebagai pengajar yang membidangi materi keagamaan menurut Tafsir (2012) perlu memahami tugasnya dan apa yang diperlukan guru PAI terutama keluasan akan wawasan dan pengetahuan mengenai ruang lingkup keagamaan. Selain itu pada Abad 21 sekarang ini dimana guru PAI dituntut untuk dapat mengaplikasikan materi pengajaran dengan teknologi. Maka diperlukan pemahaman kegaamaan yang ringkas namun mudah dimengerti oleh peserta didik dan termuat semua unsurunsur materi pembelajaran dengan pembahasan yang diberikan.

"Konten materi pembelajaran yang ingin digabungkan ke dalam aplikasi teknologi pendidikan menjadi salah satu unsur pokok utama yang dihadapi guru PAI. Dengan mengaplikasikan konten materi ajar kedalam teknologi pendidikan membuat guru PAI harus bisa memahami materi ajar yang sesuai dan dapat dipahami peserta didik." (3). Pada saat ini, menurut seorang guru PAI, "yang menjadi sasaran guru termasuk guru PAI adalah memilih konten materi pembelajaran yang menyenangkan, tetapi dibalik itu proses pembalajaran perlu dilaksanakan dengan baik dan benar, sesuai prosedur yang telah ditetapkan dalam kurikulum pendidikan." (1).

Konten materi pembelajaran yang sedang digandrungi oleh para guru adalah konten berupa vidio pembelajaran, yang menurut Muhson (2010) menjadi termasuk teknologi pendidikan. Konten vidio pembelajaran umumnya sering dituangkan oleh guru pada website, software aplikasi dan beberapa media pembelajaran berbasis Teknologi. Terdapat poin-poin yang berhubungan creating video, yaitu pertama menyiapkan materi ajar yang telah dirangkum dalam bentuk naskah; kedua proses pembuatan dengan menggunakan alat perekam, dan pastikan baik suara maupun visual gambar terekam; dan terakhir melakukan peninjauan ulang dan editing agar lebih menarik (Kelana, 2020; Rosyad, 2019).

Temuan penelitian ini, diperkuat oleh penelitian Pratama (2019) bahwa menyusun konten materi pembelajaran pada teknologi pendidikan dapat melihat stimulus dan respon yang dilakukan dalam ketercapaian isi konten yang diterima oleh peserta didik dalam pembelajaran. Isi konten yang diberikan sebagai stimulus ketersesuaian dengan arah pembelajaran dapat memberikan respon baik dari peserta didik karena upaya pemahaman yang dapat dimengerti dengan baik.

Hakam and Nurdin (2016) mengemukakan terdapat banyak sarana dalam mengimplementasikan nilai-nilai pada diri seseorang terutama melalui bahan ajar. Konten dalam video pembelajaran dapat diupayakan agar dalam kepribadian peserta didik dapat terpatri nilai pendidikan. Oleh karenanya pemilihan bahan ajar yang sesuai terhadap konten pembelajaran yang akan disampaikan sangat ditekankan agar tujuan proses pembelajaran yang dilakukan dapat tercapai. 


\section{Menyesuaikan Ruang Lingkup strategi Pembelajaran}

Ini perlu disesuaikan agar tidak terjadinya penyimpangan pemahaman terhadap materi pembelajaran yang sedang diajarkan. Aspek terpenting dalam membuat startegi pembelajaran yang sesuai dengan ruang lingkupnya yaitu terjadinya proses kognitif, afektif dan psikomotorik peserta didik (Zulfikar, 2018). Menurut seorang guru PAI, "penyesuai ruang lingkup strategi pembelajaran sebagai proses pengaktualisasian materi ajar, sehingga tujuan dari meteri ajar tersebut dapat dengan mudah diterima oleh peserta didik dan memberikan kenyamanan dalam melakukan akses pembelajaran pada aplikasi baik software maupun hardware." (3).

"Guru PAI harus memiliki startegi dalam mengajak peserta didik untuk dapat melakukan proses pembelajaran berbasis teknologi pendidikan agar pengajaran dan pembelajaran berjalan dengan efektif dan efisien. Apabila guru PAI hanya sebatas menguasai pengendalian teknologi tetapi mengabaikan kepiawaian dalam menyusun strategi pembelajaran akan menimbulkan hasil yang tidak sejalan dengan tujuan pembelajaran dan pengajaran" tegas kepala sekolah.

Strategi pembelajaran sangat penting dimiliki oleh guru karena merupakan langkah-langkah pembelajaran yang berarti luas mencakup perencanaan, kemudian pelaksanaan, dan evaluasi meliputi penilaian, dan pengayaan. Termasuk juga memilah serta menetapkan perilaku yang berubah, prosedur pendekatan, teknik, metode dan batas-batas keberhasilan termasuk norma-norma (Asrori, 2016). Strategi pembelajaran yang ada pada saat ini yaitu mengupayakan pengadaan berbasis teknologi, sehingga perlunya dilakukan penyesuaian metode dan penerapannya pada media pembelajaran. Penggunaan strategi pembelajaran yang ada saat ini memberikan dampak pada proses manajemen sekolah baik guru dan peserta didik juga pihak-pihak terkait dengan ruang lingkup sekolah (Arisanti, 2017). Pada saat ini strategi pembelajaran yang ada yaitu mengupayakan pengadaan berbasis teknologi, sehingga perlunya dilakukan penyesuaian metode dan penerapannya pada media pembelajaran (Mansir and Purnomo, 2020).

\section{Mengembangkan Wawasan Ilmu Pengetahuan}

Dengan berkembangnya teknologi pendidikan sebagai media pembelajaran sebenarnya menuntut guru untuk terus mengembangkan wawasan ilmu pengetahuan sehingga dapat meningkatkan kopetensi keilmuan terutama dalam bidang keilmuan yang sedang digelutinya. "Kecapakan guru PAI dalam mengoptimalkan pembelajaran berbasis teknologi pendidikan perlu dibarengi dengan pengembangan pemahaman dan wawasan ilmu pengetahuan agar keseimbangan proses pemutakhiran teknologi dan wawasan pengetahuan seorang guru dapat mencapai tingkat mahir pada penerapannya sebagai seorang pengajar." (2).

$\begin{array}{ccr}\text { Menurut Tafsir (2012) } & \text { seorang guru } \\ \text { perlu } & \text { meningkatkan } & \text { wawasan }\end{array}$ keilmuannya untuk dapat mencetak generasi-generasi yang berilmu, memiliki nilai budi luhur yang tinggi dan berakhlak. Kecanggihan teknologi pendidikan yang ada pada saat ini dalam dunia pendidikan tidak dapat menggantikan seorang guru sekalipun, dikarenakan guru memiliki sifat naluri kemanusiaan dan perasaan dengan akal pikirnya (Sudarsana et al., 2018; Tambak, Syahraini, et al. 2020). Lestari (2018) era globalisasi yang terjadi saat ini dengan keunggulan penerapan teknologinya bila tidak disesuaikan dengan wawasan pengetahuan manusia dapat menjadi bumerang kemerosotan bagi terbentuknya peradaban yang unggul dan generasi yang berkarakter. Maka 
dapat diinterpretasi bahwasanya seorang guru PAI sangat diperlukan upaya dalam mengembangkan wawasan ilmu pengetahuannya dan kecakapannya dalam menjalankan dan menerapkan teknologi pendidikan.

\section{PENUTUP}

Kecakapan guru PAI dalam mengoptimalisasikan pembelajaran melalui teknologi pendidikan pada SMA Darul Falah, Cihampelas, Bandung Barat, Indonesia dapat dilakukan dengan baik, pihak sekolah telah memfasilitasi guru dan peserta didik berupa media pembelajaran berbentuk website yang terpadu secara otomatis pada sebuah perangkat elektronik yang memberikan kenyamanan dan kestrukturan dalam proses pembelajaran. Guru dan peserta didik mudah dalam mengakses media elektronik tersebut serta memberikan upaya terbuka kepada seluruh komponen akses pembelajaran sehingga dapat dipantau oleh lembaga terkait dan terawasi dengan baik. Website pembelajaran tersebut memiliki tampilantampilan menarik dalam menunjang proses pendidikan pada SMA Darul Falah dan dapat diakses melalui laptop, smartphone serta perangkat serupa. Optimalisasi guru PAI dalam pembelajaran berbasis teknologi pendidikan dilakukan dengan beberapa unsur. Pertama, pentingnya memahami konten materi pembelajaran. Hal tersebut sebagai upaya agar memberikan dampak positif bagi peserta didik dalam memahami proses pembelajaran yang diberikan oleh guru. Kedua, menyesuaikan ruang lingkup strategi pembelajaran, yakni guru perlu mempersiapkan strategi terbaik dalam mengaplikasikan teknologi pendidikan yang telah disediakan untuk dapat diolah dengan baik dan memberikan hasil yang maksimal dalam proses pembelajaran. Ketiga, mengembangkan wawasan ilmu pengetahuan, teknologi pendidikan saat ini adalah tantangan nyata bagi guru agar mengubah pola pengajaran yang kuno kepada pembelajaran yang modern, dilain itu peserta didik yang berbeda generasi pun menjadi upaya guru untuk dapat memberikan pengajaran yang terbaik dan sesuai dengan perkembangan zaman yang ada.

Implikasi dari penelitian ini mengenai kecakapan guru dalam mengoptimalkan teknologi pendidikan, dirasa perlu dilakukan dengan baik dan memberikan kesadaran bagi guru dan lembaga pendidikan terkait untuk dapat memfasilitasi pembalajaran berbasis teknologi agar dibuat secara mudah dan terjangkau. Peserta didik yang telah berganti era dan generasi menjadi pemikiran mendalam bagi lembaga sekolah dan guru untuk membuat terobasan yang baru dan mendukung sesuai dengan perkembangan zaman pada genrasi yang ada sekarang.

\section{DAFTAR RUJUKAN}

Ahmad, Muhammad Yusuf, Syahraini Tambak, and Uswatun Hasanah. "Pengaruh Kecerdasan Emosional terhadap Penyesuaian Diri Mahasiswa Thailand." Al-Hikmah: Jurnal Agama dan Ilmu Pengetahuan 15.2 (2018): 16-30. https://doi.org/10.25299/alhikmah:jaip.2018.vol15(2).2374.

Ahmad, Muhammad Yusuf, and Syahraini Tambak. "Penanaman Nilai-Nilai Pendidikan Akidah Melalui Mata Pelajaran Sejarah Kebudayaan Islam (SKI)." Al-Hikmah: Jurnal Agama dan Ilmu Pengetahuan 15.1 (2018): 2441.

https://doi.org/10.25299/jaip.2018. vol15(1).1581.

Ahmad, Muhammad Yusuf, Syahraini Tambak, and Mira Syafitri. "Etika Pergaulan Islami Santri Madrasah Aliyah (MA) di Pesantren Jabal Nur Kecamatan Kandis Kabupaten Siak." Al-Hikmah: Jurnal Agama dan Ilmu Pengetahuan 13.2 (2016): 206-226. https://doi.org/10.25299/al- 
hikmah:jaip.2016.vol13(2).1524.

Ahmad, Mawardi. "Hubungan Potensi Akal dengan Kreativitas Belajar Siswa Bidang Studi Pendidikan Agama Islam di SMK Kanada Sakura Indonesia (KANSAI) Pekanbaru." Jurnal Pendidikan Agama Islam AlThariqah 2.1 (2017): 51-72. https://doi.org/10.25299/althariqa h.2017.vol2(1).647.

Ahmad, Mawardi, and Syahraini Tambak. "Penerapan Metode Diskusi Dalam Meningkatkan Hasil Belajar Murid Pada Pelajaran Fiqh." Al-Hikmah: Jurnal Agama Dan Ilmu Pengetahuan 15.1 (2018): 64-84. https://doi.org/10.25299/jaip.2018. vol15(1).1585.

Ariani, Diana. "Aktualisasi Profesi Teknologi Pendidikan Di Indonesia." Indonesian Journal of Curriculum and Educational Technology Studies 5. 1 (2017):1-9. doi:10.15294/ijcets.v5i1.14244.

Arif, Khusnan. "Teknologi Pembelajaran PAI (Pendidikan Agama Islam) Dalam Paradigma Konstruktivistik." Fikroh: Jurnal Pemikiran Dan Pendidikan Islam 4. 2 (2011): 154-167. https://jurnal.stai-

alazharmenganti.ac.id/index.php/fikr oh/article/view/18.

Arisanti, Devi. "Manajemen Lingkungan Pendidikan Dalam Perspektif Islam." Jurnal Pendidikan Agama Islam AlThariqah 1. 1 (2017): 71-86. doi:10.25299/althariqah.2016.vol1(1 ).620.

Asiah, Nur. "Inovasi Pembelajaran Pendidikan Agama Islam Melalui ELearning Di SMA Budaya Bandar Lampung." Jurnal MUDARRISUNA: Media Kajian Pendidikan Agama Islam 6. 1 (2016): 77-101.

Asrori, Mohammad. "Pengertian, Tujuan Dan Ruang Lingkup Strategi Pembelajaran." MADRASAH 6. 2 (2016): 26-37. doi:10.18860/jt.v6i2.3301.

Dhawan, Shivangi. "Online learning: A panacea in the time of COVID-19 crisis." Journal of Educational Technology Systems 49.1 (2020): 522.

Go, Ingyu. "Analysis on Trends of Technology Education Shown in National Curriculum at the Elementary Level in Republic of Korea." International Journal of Technology and Design Education, 31. 2 (2021): 23-54, doi:10.1007/s10798-019-09555-z.

Hadisi, La, and Wa Muna. "Pengelolaan Teknologi Informasi Dalam Menciptakan Model Inovasi Pembelajaran (E-Learning)." Jurnal Al-Ta'dib 8. 1 (2015): 17-40.

Hakam, K. A., and E. S. Nurdin. Metode Internalisasi Nilai-Nilai Untuk Memodifikasi Perilaku Berkarakter. Maulana Media Grafika, 2016.

Hamzah, Desi Sukenti, Syahraini Tambak, and Wisudatul Ummi Tanjung. "Overcoming self-confidence of Islamic religious education students: The influence of personal learning model." Journal of Education and Learning (EduLearn) 14.4 (2020): 582-589. https://doi.org/10.11591/edulearn. v14i4.16759.

Hamzah, Hamzah, Syahraini Tambak, and Nella Ariyani. "Upaya Guru Pendidikan Agama Islam dalam Pembentukan Kepribadian Islam Siswa di SMA Negeri 2 Kelayang Kabupaten Indragiri Hulu." AlHikmah: Jurnal Agama dan Ilmu Pengetahuan 14.1 (2017): 76-95. https://doi.org/10.25299/alhikmah:jaip.2017.vol14(1).1528.

Ignatov, Andrey, et al. "Learned smartphone isp on mobile npus with deep learning, mobile ai 2021 challenge: Report." Proceedings of the IEEE/CVF Conference on Computer Vision and Pattern Recognition. 2021.

Kelana, I. "Cara Mudah Buat Konten Video Pembelajaran Menarik." Republika, 2020, 
https://www.republika.co.id/berita/ qkgikq374/cara-mudah-buat-kontenvideo-pembelajaran-menarik.

Lase, Delipiter. "Pendidikan Di Era Revolusi Industri 4.0." JURNAL SUNDERMANN 12. 2 (2019): 89-102.

Lestari, Sudarsri. "Peran Teknologi Dalam Pendidikan Di Era Globalisasi." EDURELIGIA: Jurnal Pendidikan Agama Islam 2. 2 (2018): 94-100. https://ejournal.unuja.ac.id/index.ph $\mathrm{p} /$ edureligia.

Lubis, Sarmadhan. "Peningkatan Profesionalisme Guru PAI Melalui Kelompok Kerja Guru (KKG)." Jurnal Pendidikan Agama Islam Al-Thariqah 2. 2 (2017): 189-205, doi:10.25299/althariqah.2017.vol2(2 ).1045.

Maghfiroh, Muliatul, and Sri Nurhayati. "Peningkatan Strategi Dan Metode Pembelajaran Guru PAI Dalam Era Revolusi Industri 4 . 0." Pêrdikan: Journal of Community Engagement 2. 1 (2020): 10-19.

Mansir, Firman, and Halim Purnomo. "Optimalisasi Peran Guru PAI Ideal Dalam Pembelajaran Fiqh Di Masa Pandemi Covid-19." Jurnal Pendidikan Agama Islam Al-Thariqah 5. 2 (2020): 97-105. https://doi.org/10.25299/althariqah.2020.vol5(2).5692.

Melani, Agustina. "Jack Ma Ubah Pendidikan Agar Bersaing Dengan Robot." Liputan 6, https://www.liputan6.com/bisnis/re ad/3238241/jack-ma-ubahpendidikan-agar-bersaing-denganrobot. Accessed 1 Apr. 2021.

Muhson, Ali. "Pengembangan Media Pembelajaran Berbasis Teknologi Informasi." Jurnal Pendidikan Akuntansi Indonesia 8. 2 (2010): 178185.

https://journal.uny.ac.id/index.php/j pakun/article/view/949.

Nasution, Syaiful Hamzah. "Pentingnya Literasi Teknologi Bagi Mahasiswa Calon Guru Matematika." Jurnal Kajian Pembelajaran Matematika 2. 1
(2018): 14-18.

Noer, Ali, Syahraini Tambak, and Harun Rahman. "Upaya Ekstrakurikuler Kerohanian Islam (ROHIS) dalam Meningkatkan Sikap Keberagamaan Siswa di SMK Ibnu Taimiyah Pekanbaru." Jurnal Pendidikan Agama Islam Al-Thariqah 2.1 (2017): 21-38. https://doi.org/10.25299/althariqah. 2017.vol2(1).645.

Nu'man, Ahmad Zanin. "Efektifitas Penerapan E-Learning Model Edmodo Dalam Pembelajaran Pendidikan Agama Islam Terhadap Hasil Belajar Siswa." Duta.Com 7. 1 (2014): 58-72.

Nurdin, Arbain. "Inovasi Pembelajaran Pendidikan Agama Islam Di Era Information and Communication Technology." Tadrîs 11. 1 (2016): 2938.

Pratama, Ujang Nendra, and Haryanto. "Pengembangan Game Edukasi Berbasis Android Tentang Domain Teknologi Pendidikan." Jurnal Inovasi Teknologi Pendidikan 4. 2 (2017): 6784.

Pratama, Yoga Anjas. "Relevansi teori belajar behaviorisme terhadap pendidikan agama islam." Jurnal Pendidikan Agama Islam Al-Thariqah 4.1 (2019): 38-49. doi:10.25299/althariqah.2019.vol4(1).2718.

Ramdani, Rijki, et al. "Media Pembelajaran E-Learning Dalam Pembelajaran Pendidikan Agama Islam Di SMA Laboratorium Percontohan UPI Bandung." TARBAWY: Indonesian Journal of Islamic Education 5. 1 (2018):

47-62. doi:10.17509/t.v5i1.13332.

Richter, Eric, et al. "Four Reasons for Becoming a Teacher Educator: A Large-Scale Study on Teacher Educators' Motives and Well-Being." Teaching and Teacher Education 102 (2021): 103322. doi:10.1016/j.tate.2021.103322.

Rosyad, Ali Miftakhu. "Urgensi Inovasi Pembelajaran Dalam Pendidikan 
Agama Islam." Al-Afkar Journal for Islamic Studies 2. 1 (2019): 64-86. doi:10.5281/zenodo.3553865.

Sawaluddin, Sawaluddin. "Konsep Evaluasi Dalam Pembelajaran Pendidikan Islam." Jurnal Pendidikan Agama Islam Al-Thariqah 3. 1 (2018): 39-52.

doi:10.25299/althariqah.2018.vol3(1 ).1775.

Sintawati, Mukti, and Fitri Indriani. "Pentingnya Technological Pedagogical Content Knowledge (Tpack) Guru Di Era Revolusi Industri 4.0." SEMINAR NASIONAL PAGELARAN PENDIDIKAN DASAR NASIONAL (PPDN) 2019, (2019): 1722. http://jayapanguspress.org.

Subkhan, E. Sejarah Dan Paradigma Teknologi Pendidikan Untuk Perubahan Sosial. Kencana, 2016.

Sudarsana, I. Ketut, et al. Teknologi Dan Aplikasinya Dalam Dunia Pendidikan. Jayapangus Press, 2018, http://jayapanguspress.org.

Sukenti, Desi, and Syahraini Tambak. "Developing Indonesian Language Learning Assessments: Strengthening the Personal Competence and Islamic Psychosocial

Teachers." International Journal of Evaluation and Research in Education 9.4 (2020): 1079-1087.

Sukenti, Desi, and Syahraini Tambak. "Strengthening Islamic Psychosocial and Self-confidence in Develophing Student Thinking Creative." ICOSEEH 20194 (2019): 446-453.

Sunarti, Sunarti. "Membangun Kemampuan Literasi Informasi Guru PAI Di Era Teknologi Informasi." Jurnal Ilmiah Pedagogy 7. 1 (2017): 37-49.

Surani, Dewi. "Studi Literatur: Peran Teknolog Pendidikan Dalam Pendidikan 4.0." Prosiding Seminar Nasional Pendidikan FKIP 2. 1 (2019): 56-69.

https://jurnal.untirta.ac.id/index.php /psnp/article/view/5797.
Suwastika, I. Wayan Kayun. "Pengaruh ELearning Sebagai Salah Satu Media Pembelajaran Berbasis Teknologi Informasi Terhadap Motivasi Belajar Mahasiswa." Jurnal Sistem Dan Informatika (JSI) 13. 1 (2018): 1-5. https://jsi.stikombali.ac.id/index.php/jsi/article/view/ 185.

Syarif, Miftah. "Hakekat Manusia Dan Implikasinya Pada Pendidikan Islam." Jurnal Pendidikan Agama Islam AlThariqah 2. 2 (2017): 35-47. doi:10.25299/althariqah.2017.vol2(2 ).1042.

Tafsir, Ahmad. Filsafat Pendidikan Islam. 5th ed., Remaja Rosdakarya, 2012.

Tambak, Syahraini, et al. "Internalization of Riau Malay Culture in Developing the Morals of Madrasah Ibtidaiyah Students." Al Ibtida: Jurnal Pendidikan Guru MI 7.1 (2020): 6984.

https://doi.org/10.24235/al.ibtida.s nj.v7i1.5954.

Tambak, Syahraini, and Desi Sukenti. "Pengembangan profesionalisme guru madrasah dengan penguatan konsep khalifah." Hayula: Indonesian Journal of Multidisciplinary Islamic Studies 4.1 (2020): 41-66. https://doi.org/10.21009/004.01.0.

Tambak, Syahraini, et al. "Profesionalisme Guru Madrasah: Internalisasi Nilai Islam Dalam Mengembangkan Akhlak Aktual Siswa." Jurnal Pendidikan Agama Islam Al Thariqah 5.2 (2020): 80-96. DOI: https://doi.org/10.25299/althariqah.2020.vol5(2).5885.

Tambak, Syahraini, and Desi Sukenti. "Strengthening Islamic behavior and Islamic psychosocial in developing professional madrasah teachers." Cakrawala Pendidikan: Jurnal Ilmiah Pendidikan 39.1 (2020): 65-78.

Tambak, Syahraini. "Pendidikan Etika Bergaul Islami Dalam Keluarga "Nilai Pendidikan Etika Berlaku Adil Orangtua dengan Anak dalam 
Pergaulan Keluarga Perspektif Hadits"." Jurnal Pendidikan Agama Islam Al-Thariqah 4.1 (2019): 1-20. https://doi.org/10.25299/althariqah.2019.vol4(1).2910.

Tambak, Syahraini, Amril M, Zuriatul Khairi, and Desi Sukenti. "Development of Madrasah Teacher Professionalism by Strengthening the Khalifah Concept and Islamic Psychosocial Perspective." International Conference on Islamic Education (ICIE 2018). Atlantis Press, 2018. https://doi.org/10.2991/icie18.2018.7.

Tambak, Syahraini. "Filsafat Idealisme dan Implikasinya pada Teori Pendidikan." Al-Hikmah 11.1 (2014): 61-75.

Tambak, Syahraini, M. Yusuf Ahmad, and Desi Sukenti. "Strengthening Emotional Intelligence in Developing the Madrasah Teachers' Professionalism (Penguatan Kecerdasan Emosional dalam Mengembangkan Profesionalisme Guru Madrasah)." Akademika 90.2 (2020).

https://doi.org/10.17576/akad2020-9002-03.

Tambak, Syahraini, Amril Amril, and Desi Sukenti. "Islamic Teacher Development: Constructing Islamic Professional Teachers Based on The Khalifah Concept." Nazhruna: Jurnal Pendidikan Islam 4.1 (2021): 117135.

https://doi.org/10.31538/nzh.v4i1. 1055.

Tambak, Syahraini. "Jihad Pendidikan: Konsep dan Upaya Memajukan Pendidikan Indonesia." AlHikmah 7.14 (2010): 1-15.
Tambak, Syahraini, and Desi Sukenti. "Exploring Methods for Developing Potential Students in Islamic Schools in the Context of Riau Malay Culture." Revolution 4 (2020): 343-351.

Troll, Eve Sarah, Malte Friese, and David D. Loschelder. "How students' selfcontrol and smartphone-use explain their academic performance." Computers in Human Behavior 117 (2021):

106624. https://doi.org/10.1016/j.chb.2020.1 06624.

Wei, Huei-Chuan, and Chien Chou. "Online learning performance and satisfaction: do perceptions and readiness matter?." Distance Education 41.1 (2020): 48-69.

Wijaya, Etistika Yuni, et al. "Transformasi Pendidikan Abad 21 Sebagai Tuntutan Pengembangan Sumber Daya Manusia Di Era Global." Prosiding Seminar Nasional Pendidikan Matematika 20161 (2016): 63-78.

Yazdi, Mohammad. "E-Learning Sebagai Media Pembelajaran Interaktif Berbasis Teknologi Informasi." Jurnal Ilmiah Foristek, 2.1 (2012): 43-52.

Yoon, Meehyun, Jungeun Lee, and Il-Hyun Jo. "Video learning analytics: Investigating behavioral patterns and learner clusters in video-based online learning." The Internet and Higher Education 50 (2021): 100806. https://doi.org/10.1016/j.iheduc.202 1.100806.

Zulfikar, Dimas Ariyanto. Pemanfaatan Informasi Teknologi Dalam Upaya Peningkatan Mutu Pembelajaran Pendidikan Agama Islam Di SMK Negeri 1 Ponorogo. Institut Agama Islam Negeri Ponorogo, 2018, http://etheses.iainponorogo.ac.id/54 89/1/Dimas Ariyanto Z.pdf. 